\title{
Equine chorionic gonadotrophin (eCG) after weaning in reproductive performance of sows from distinct parturition order
}

\author{
Gonadotrofina coriônica equina (eCG) após o desmane no desempenho \\ reprodutivo de fêmeas suínas com diferentes ordens de partos
}

\begin{abstract}
Cláudio Francisco Brogni (D*, Lain Uriel Ohlweiler (D), Joana Claudia Mezzalira (D), Alceu Mezzalira (D) Universidade do Estado de Santa Catarina (UDESC), Florianópolis, SC, Brazil
\end{abstract}

\begin{abstract}
The weaning to estrus interval (WEI) and litter size are points that influences sow reproductive parameters and consequently the swine production. This study evaluated the effect of equine chorionic gonadotrophin (eCG), applied 5 hours after weaning, in sows of 1 st to 5th parturition order (PO1-5) and sows with parturition order equal to or greater than $6(\mathrm{PO} 6+)$ on reproductive parameters. PO1-5 sows $(n=240)$ were allocated into three groups: control group $(\mathrm{n}=80)$, received $4 \mathrm{ml}$ of saline solution; eCG800 group ( $n=80$ ), received 800 UI of eCG; and eCG1000 group ( $n=80)$, received $1000 \mathrm{UI}$ of eCG. PO6+ sows $(n=160)$ were allocated in control group ( $n=80$ ), receiving $5 \mathrm{ml}$ of saline solution, and eCG1000 group ( $n=80$ ), that received $1000 \mathrm{IU}$ of eCG. The parameters of estrus duration, number of inseminations, birth order, number and weight of live
\end{abstract}

* Corresponding author: claudiobrogni@gmail.com Received: Aug 4 2020 | Approved: Oct 222020 piglets were evaluated. Chi-square test and analysis of variance with Tukey test were used in MIXED procedure of statistical package SAS ( $p<0.05$ ). An increased estrus duration and a mean increase of 1.5 piglets per litter was observed in eCG1000 group of PO1-5 sows, without affecting their mean weight. For PO6+ sows, the eCG1000 group was increased by one piglet per litter without interfering in the mean weight at birth. The economic analysis revealed a revenue of $400 \%$ of eCG investment in the PO1-5 sows, and $268 \%$ in the PO6+ group. It was concluded that the use of $1000 \mathrm{UI}$ of eCG improves the reproductive parameters of sows of both (PO1-5 and $\mathrm{PO} 6+$ ) parturition orders.

Keywords: Farrowing order. Litter size. Weaning interval. 


\section{Resumo}

O intervalo de desmame/cio (IDC) e o tamanho da leitegada são pontos que influenciam os parâmetros reprodutivos das porcas e, consequentemente, a produção suinícola. Este estudo avaliou o efeito da gonadotrofina coriônica equina (eCG), aplicada 5 horas após o desmame, em porcas de $1^{a}$ à $5^{a}$ ordem de parto (P01-5) e em porcas com ordem de parto igual ou superior a $6(\mathrm{PO} 6+)$ sobre os parâmetros reprodutivos. As porcas PO1-5 ( $n=240)$ foram alocadas em três grupos: grupo controle $(n=80)$, recebendo $4 \mathrm{ml}$ de solução salina; grupo eCG800 $(n=80)$, recebendo 800 Ul de eCG; e grupo eCG1000 $(n=80)$, recebendo 1000 $U I$ de eCG. As porcas PO6+ $(n=160)$ foram alocadas em grupo controle $(n=80)$, recebendo $5 \mathrm{ml}$ de solução salina, e grupo eCG1000 ( $n=80)$, recebendo $1000 \mathrm{UI}$ de eCG. Foram avaliados os parâmetros duração do estro, número de inseminações, ordem de parto, número e peso dos leitões vivos. Para análise estatística, os dados foram submetidos ao Qui-quadrado e à análise de variância e teste de Tukey, usando o procedimento MIXED do pacote estatístico SAS $(p<0,05)$. Observouse aumento da duração do estro e aumento médio de 1,5 leitões por leitegada, sem alteração no peso médio no grupo eCG1000 de porcas PO1-5. Para porcas PO6+, o grupo eCG1000 incrementou um leitão por leitegada, sem interferir no peso médio ao nascimento. $A$ análise econômica revelou uma receita de $400 \%$ do investimento em eCG nas porcas P01-5 e 268\% no grupo PO6+. Concluiu-se que o uso de $1000 \mathrm{UI}$ de eCG melhora os parâmetros reprodutivos de porcas de ambas ordens de partos (PO1-5 e PO6+).

Palavras-chave: Ordem de parto. Tamanho da leitegada. Intervalo desmame/cio.

\section{Introduction}

Luteinizing hormone (LH) suppression at the start of lactation is related to an effect of lactation itself, and not to a hormonal block due to pregnancy or parturition, since LH secretion is not suppressed in late gestation of sows (Ziecik et al., 1982). Soon after parturition, sows show episodic LH secretion, which is suppressed 66 to 78 hours afterwards (De Rensis et al., 1993). Thus, the piglets suckling causes LH inhibition, which blocks follicular development and leads to a lactational anestrous in sows (De Rensis et al., 1993). The follicle-stimulating hormone (FSH) concentration in lactating and weaned sows is not different soon after farrowing, suggesting that FSH is not a limiting factor for follicular development in the early postpartum period (De Rensis et al., 1993). However, an abnormal follicular growth in the immediate postpartum period makes the follicle not fully responsive to the LH ovulatory peak, preventing ovulation at the appropriate time (Knox, 2015; Koketsu et al., 2017). To evaluate lactational anestrus, Varley and Foxcroft (1990) removed the piglets just after birth and observed that although some sows return to normal estrus in two weeks, a high incidence of cysts and an increased birth to conception interval were verified.

Therefore, exogenous gonadotrophins are potential alternatives to induce and synchronize estrus in sows. This may facilitate reproductive management and increase fertilization, which results in an increased number of piglets born (Hühn et al., 1996). The drugs most commonly used to manipulate follicular development, estrous cycle and ovulation are eCG, hCG, GnRH and its analogues, PGF2 $\alpha$ and its analogues, and progestogens (Moretti et al., 2013). Of these, eCG is able to bind to FSH and LH receptors, and thus shows follicle stimulating and luteinizing activity. In sows, this hormone was used in ovarian activity resumption to reduce weaning to estrus interval (WEI) and to increase follicular growth after weaning (Hühn et al., 1996). Due to the great variability of results in the literature, it is opportune to improve the knowledge about the use of eCG in weaned sows.

This study aimed to evaluate the effects of two doses (800 and $1000 \mathrm{UI}$ ) of eCG, applied in the post-weaning period, on sows' reproductive parameters. Estrus capacity induction, WEI reduction and the number of live piglets born were evaluated in sows from two categories: parturition order 1 to 5 (PO1-5), and parturition order equal to or greater than 6 (PO6+). 


\section{Material and methods}

The experiment was performed on a commercial pig farm located in Santa Catarina

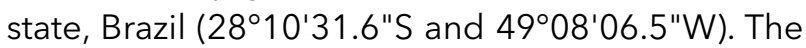
herd was composed of 958 females and 5 males from Naïma lineage (Choice Genetics ${ }^{\circledR}$ ), a highly proliferating strain, which was used in the region of the development of the experiment. Only healthy females in the post-weaning period were used in the study. The experiment was approved by the Ethics Committee on the Use of Animals (CEUA/UDESC), under number 3444020616. The equine chorionic gonadotrophin (Novormon ${ }^{\circledR}$, Zoetis, Campinas, Brazil) and cloprostenol sodium (Sincrocio ${ }^{\circledR}$, Ouro Fino Saúde Animal, Cravinhos, Brazil) were utilized to compose the treatments.

The piglets were weaned at 21 days age, and females were housed in individual gestation cages with a compacted floor. They were fed with 2-3 $\mathrm{kg}$ of $14 \%$ protein feed and water ad libitum in automatic drinking troughs. Feed formulated based on ground corn, soybean meal, rice bran, vitamins and minerals for pregnancy.

For submission to the experiments, the females were allocated into two categories: PO1-5 females with 1 to 5 parturition order, and $\mathrm{PO} 6+$ females with a parturition order equal to or greater than 6. The distribution of the females within each experimental group was performed in a random manner.

Experiment 1 was performed with PO1-5 sows ( $n=240)$ submitted to one of three treatments: control group ( $n=80)$, in which the females received $4 \mathrm{ml}$ of saline solution; eCG800 group ( $=80)$, in which the females received $800 \mathrm{IU}(4 \mathrm{ml})$ of eCG (Novormon ${ }^{\circledR}$ ) IM; and eCG1000 group (n $=80)$, in which females received $1000 \mathrm{IU}(5 \mathrm{ml})$ of eCG injected in a deep intramuscular route. In all treatments, the injections were performed 5 hours after weaning, when the females were allocated to the respective experimental groups, in order to allow a similar number of females from each farrowing order.

Experiment 2 was performed with $\mathrm{PO} 6+$ females ( $n=160)$, submitted to one of two treatments: control group ( $n=80)$, in which females received $5 \mathrm{ml}$ of saline solution, and eCG1000 Group ( $\mathrm{n}=$
80), in which females received $1000 \mathrm{UI}(5 \mathrm{ml})$ eCG $\left(\right.$ Novormon $\left.{ }^{\circledR}\right)$. The injections were performed 5 hours after weaning.

Estrus recognition was performed by tolerance reflex to lumbar pressure, and the first demonstration of this reflex was considered as the start of estrus. This procedure was performed twice a day, starting 24 hours after eCG injection, at 8 am and $5 \mathrm{pm}$. A trained person led the boar along a corridor in front of the sows' stalls during a onehour period, allowing visual, olfactory and physical (naso-nasal) contact between females and male. At the same time, another trained person evaluated the behavior of females, observing restlessness, vulvar edema and ear stiffness. However, only females with positive lumbar pressure reflex exerted by man (RTH), characterized by sows remaining immobile during manual pressure on their back, were considered in estrus.

Semen was obtained from five pre-evaluated boars, used in a random manner, according to the availability and requirement of collection and processing. Only ejaculates with motility higher than $70 \%$ and vigor superior to 3 were used, as recommended by the Brazilian College of Animal Reproduction (CBRA, 2013). The motility and morphology evaluations were performed under light microscopy, with 10 to 40x magnification. Each sow was inseminated at least two times. Each insemination dose $(60 \mathrm{ml})$ contained about 2 to $3 \times 10^{9}$ sperm cells, diluted in commercial diluent (BTS ${ }^{\circledR}$ ), and stored refrigerated at $16{ }^{\circ} \mathrm{C}$ for up to 48 hours.

All sows were submitted to cervical insemination, performed with a foam-tipped pipette, inserted through the vagina and fixed to the cervix, with semen deposition in the cervical lumen. The insemination was performed in the presence of a boar, starting 24 hours after the positive RTH reflex, and repeated every 12 hours, while reflex was present.

The conception rate was determined after pregnancy diagnosis performed by ultrasonography between the 25th and 30th day after the last artificial insemination. Females with anechoic contents inside the uterine lumen, as well as the presence of the conceptus, were considered pregnant. The conception rate was calculated by 
the percentage of pregnant females from each treatment in relation to the number of sows of each treatment. The farrowing rate was calculated from the total number of females that farrowed in relation to the total number of pregnant females.

Female parturition was induced after 113 days of gestation, counted from the last insemination, with an injection of $0.268 \mathrm{mg}$ of cloprostenol sodium (Sincrocio ${ }^{\circledR}$ ). Parturition took place around 24 to 36 hours after application. To calculate the total number of piglets, those born alive, dead and mummified were considered. For the birth weight calculation, only viable piglets were considered.

\section{Statistical analysis}

The qualitative data were submitted to the Chisquare test, and the other data were submitted to the analysis of variance using the MIXED procedure of the statistical package SAS (SAS Institute Inc, 2008). The data were previously tested for normality of the residues by the KolmogorovSmirnov test. The means were compared by Tukey test, with 5\% significance level. The statistical model used included as explanatory variables the effect of groups, the order of birth and the interaction between them.

The economic analysis was carried out based on the costs of eCG acquisition and the increase in revenue provided by the increase in the number of live piglets in the litters. The value to determine the eCG cost during the experiment was based on the market value of Novormon ${ }^{\circledR}$ in 2016. Likewise, the sales value of the piglets was calculated based on the values received at the time of the experiment. As a way of maintaining the validity of these values over time, reference values were converted to US dollars.

\section{Results}

The rate of induction to estrus after weaning was similar between treatments and between parturition orders. The PO1-5 sows (order of delivery between 1 and 5) from the control, eCG800 and eCG1000 groups showed $88 \%$, 93\% and 95\% of estrus induction after weaning, respectively. For $\mathrm{PO} 6+$ females (order of delivery equal to or greater than 6), the control and eCG1000 groups resulted in $89 \%$ and $88 \%$ of return to estrus, respectively.

PO1-5 females showed a reduction in the weaning to estrus interval (WEI) when treated with eCG in comparison to the control group. However, in parallel, increased duration of estrus in the females treated with $1000 \mathrm{UI}$ of eCG was observed in comparison with control group (Table 1). The mean number of inseminations was similar among all experimental groups.

Table 1 - Effect of two eCG doses on the weaning to estrus interval (WEI), estrus duration and insemination number of sows from parturition order 1 to 5

\begin{tabular}{lccc}
\hline \multirow{2}{*}{ Groups } & WEI & Estrus duration & Insemination \\
\cline { 2 - 4 } & hours & hours & number \\
\hline Control & $87.14 \pm 1.83^{\mathrm{A}}$ & $42.70 \pm 1.40^{\mathrm{A}}$ & $3.53 \pm 0.087^{\mathrm{A}}$ \\
eCG800 & $79.08 \pm 1.78^{\mathrm{B}}$ & $45.70 \pm 1.37^{\mathrm{AB}}$ & $3.52 \pm 0.084^{\mathrm{A}}$ \\
eCG1000 & $76.73 \pm 1.75^{\mathrm{B}}$ & $47.34 \pm 1.35^{\mathrm{B}}$ & $3.54 \pm 0.083^{\mathrm{A}}$ \\
\hline
\end{tabular}

Note: ${ }^{A B}$ Different letters in the same column indicate statistical difference $(p<0.05)$.

In PO1-5 group, WEl reduction was observed as the parturition order progressed, when data from each parturition order was separately evaluated, and disregarding the treatment effects (Table 2). Multiparous sows (PO-3, PO-4 and PO-5) showed a lower WEI when compared to primiparous ones, similar to PO-2 (Table 2). Regarding the estrus duration, the opposite behavior was observed, with shorter estrus duration observed in primiparous sows, increasing at the second parturition, 
and stabilizing at third farrowing (Table 2). As consequence, there was also an increased number of inseminations performed. In contrast, females with six or more delivery were not influenced by the use of $1000 \mathrm{UI}$ of eCG for the variables WEI $(82.90 \mathrm{~h})$, duration of estrus (47.67 h), and number of inseminations (3.80) when compared to control group $(\mathrm{WEI}=81.47 \mathrm{~h}$, estrus duration $=45.01 \mathrm{~h}$, and insemination number $=3.58$ ).

Conception and farrowing rates were not influenced by treatments. The females from the PO1-5 group showed a conception rate of 95.7, 89.2 and $88.2 \%$ for control, eCG800 and eCG1000 treatments, respectively $(p>0.05)$. The farrowing rates of the same sows were $91.4,89.2$ and $86.8 \%$ for control, eCG800 and eCG1000 groups, respectively $(p>0.05)$. Similarly, females of the OP6 + group had identical conception (94.37 and $88.57 \%$ ) and farrowing rates (94.37 and $87.14 \%$ ) for the control and eCG1000 groups, respectively ( $p>0.05$ ).

The P01-5 sows showed an increased number of piglets born and live piglets in the eCG1000 group in comparison to control group (Table 3). The mean increase was 1.5 live piglets. In contrast, no difference was observed between treatment eCG800 and control. Likewise, no statistical differences were observed in total number of piglets and live piglets between eCG800 and eCG1000 treatments. Yet, the treatments did not influence the number of stillborn and mummified piglets (Table 3), nor the mean weight of the piglets. The live litter weight was not different between the control and eCG treatments. However, a reduction on total weight of live litter was observed in eCG800 and eCG1000 treatments (Table 3).

There was no influence of eCG on the total number of piglets in the litters of OP6+ sows. However, there was an increase of one live piglet per litter as a function of the $1000 \mathrm{UI}$ of eCG treatment, compared to control (Table 4). Meanwhile, the stillborn and mummified piglet numbers did not differ between groups. The total weight of live litter and the mean weight of piglets were not influenced by $1000 \mathrm{UI}$ eCG treatment (Table 4).

Table 2 - Comparative data of weaning to estrus interval (WEI), estrus duration, and insemination number of sows from OP1-5 group (parturition order 1 to 5 )

\begin{tabular}{cccc}
\hline \multirow{2}{*}{ Parturition number } & WEI & Estrus duration & \multicolumn{2}{c}{ Insemination } \\
\cline { 2 - 4 } & hours & hours & number \\
\hline 1 & $85.88 \pm 1.97^{\mathrm{A}}$ & $38.15 \pm 1.51^{\mathrm{A}}$ & $3.19 \pm 0.09^{\mathrm{A}}$ \\
2 & $81.20 \pm 2.14^{\mathrm{AB}}$ & $43.69 \pm 1.64^{\mathrm{B}}$ & $3.40 \pm 0.10^{\mathrm{A}}$ \\
3 & $78.90 \pm 2.55^{\mathrm{B}}$ & $50.34 \pm 1.95^{\mathrm{C}}$ & $3.88 \pm 1.12^{\mathrm{B}}$ \\
5 & $74.00 \pm 4.25^{\mathrm{B}}$ & $53.40 \pm 3.24^{\mathrm{C}}$ & $3.92 \pm 0.19^{\mathrm{B}}$ \\
& $77.99 \pm 2.05^{\mathrm{B}}$ & $49.40 \pm 1.55^{\mathrm{C}}$ & $3.72 \pm 0.09^{\mathrm{B}}$ \\
\hline
\end{tabular}

Note: ${ }^{A B C}$ Different letters in the same column indicate statistical difference $(p<0.05)$

Table 3 - Effect of two doses of eCG (800 and 1000 UI) on litter parameters on sows of 1 st to 5 th parturition order

\begin{tabular}{lccccc}
\hline Groups & $\begin{array}{c}\text { Mean number } \\
\text { of pinglets }\end{array}$ & $\begin{array}{c}\text { Mean number of } \\
\text { live piglets }\end{array}$ & $\begin{array}{c}\text { Stillborn and } \\
\text { mummified } \\
\text { piglets }\end{array}$ & $\begin{array}{c}\text { Total live litter } \\
\text { weight } \\
\mathbf{( k g )}\end{array}$ & $\begin{array}{c}\text { Piglet mean } \\
\text { weight } \\
(\mathbf{k g})\end{array}$ \\
\hline Control & $14.14 \pm 0.36^{\mathrm{A}}$ & $12.64 \pm 0.30^{\mathrm{A}}$ & $1.51 \pm 0.17^{\mathrm{A}}$ & $16.47 \pm 1.12^{\mathrm{AB}}$ & $1.36 \pm 0.036^{\mathrm{A}}$ \\
eCG800 & $14.45 \pm 0.36^{\mathrm{AB}}$ & $13.03 \pm 0.30^{\mathrm{AB}}$ & $1.31 \pm 0.17^{\mathrm{A}}$ & $16.36 \pm 1.20^{\mathrm{A}}$ & $1.30 \pm 0.038^{\mathrm{A}}$ \\
eCG1000 & $15.25 \pm 0.35^{\mathrm{B}}$ & $14.13 \pm 0.29^{\mathrm{B}}$ & $1.13 \pm 0.17^{\mathrm{A}}$ & $19.60 \pm 1.10^{\mathrm{B}}$ & $1.34 \pm 0.035^{\mathrm{A}}$ \\
\hline
\end{tabular}

Note: ${ }^{A B}$ Different letters in the same column indicate statistical difference $(p<0.05)$. 
Table 4 - Effect of 1000 UI eCG on litter parameters on sows from parturition order equal or greater than 6

\begin{tabular}{lccccc}
\hline Groups & $\begin{array}{c}\text { Mean number } \\
\text { of pinglets }\end{array}$ & $\begin{array}{c}\text { Mean number of } \\
\text { live piglets }\end{array}$ & $\begin{array}{c}\text { Stillborn and } \\
\text { mummified } \\
\text { piglets }\end{array}$ & $\begin{array}{c}\text { Total live litter } \\
\text { weight } \\
(\mathbf{k g})\end{array}$ & $\begin{array}{c}\text { Piglet mean } \\
\text { weight } \\
(\mathbf{k g})\end{array}$ \\
\hline Control & $14.50 \pm 0.33^{\mathrm{A}}$ & $12.79 \pm 0.32^{\mathrm{A}}$ & $1.97 \pm 0.21^{\mathrm{A}}$ & $17.49 \pm 1.17^{\mathrm{A}}$ & $1.35 \pm 0.052^{\mathrm{A}}$ \\
$\mathrm{eCG} 1000$ & $15.32 \pm 0.3^{\mathrm{A}}$ & $13.82 \pm 0.33^{\mathrm{B}}$ & $1.45 \pm 0.22^{\mathrm{A}}$ & $18.67 \pm 1.03^{\mathrm{A}}$ & $1.40 \pm 0.045^{\mathrm{A}}$ \\
\hline
\end{tabular}

Note: ${ }^{A B}$ Different letters in the same column indicate statistical difference $(p<0.05)$.

For economic evaluation, the price of Novormon was converted to US dollar, which was equivalent to US $\$ 46.35$ per bottle. Thus, each $\mathrm{ml}$ of the product corresponding to $200 \mathrm{UI}$ of eCG had a cost of US\$1.854. Therefore, in the females of the $800 \mathrm{UI}$ group receiving $4 \mathrm{ml}$, there was an investment of US\$7.41, while the females of the $1000 \mathrm{UI}$ group received $5 \mathrm{ml}$, with an investment of US\$9.27. The price of piglets delivered to the industry was estimated at US\$3.55 per live $\mathrm{kg}$, and the piglets were delivered weighing $7 \mathrm{~kg}$. Based on these values, each additional piglet delivered represented revenue of US\$24.85. Thus, for OP1-5 sows, which provided 1.5 additional piglets, the revenue increase was US\$37.275, resulting in financial feedback of US $\$ 4.0$ for each dollar employed. In females of OP6+, which provided one additional piglet per litter, the revenue was US\$24.85, resulting in financial feedback of US\$2.68 for each dollar employed.

\section{Discussion}

Reproductive failures are an important bottleneck in modern swine farming, impacting the success of pig-breeding activity. A good breeder is the one that produces the largest number of piglets weaned per year, and for this, an early return to estrus in the postpartum period is necessary.

Hühn et al. (1996) evaluated different hormonal protocols for two decades, demonstrating that the use of 600 to 1000 IU of eCG 24 hours after weaning is effective for the sow's estrus return after weaning. In this study, the rate of estrus return after weaning was high, varying from 88 to $95 \%$. Although the rate of estrus return observed was numerically superior, using $800 \mathrm{UI}$ (93\%) or 1000 UI of eCG (95\%), there was no statistical difference to the rate for the PO1-5 control group (88\%). This demonstrated no effect of eCG, regardless of the dose used. The PO6+ females showed the same behavior, with no statistical differences observed in estrus return rate between control (89\%) and eCG1000 (88\%) groups.

Reproductive efficiency is directly related to the number of non-productive days (NPD), which in turn is directly influenced by the WEI (Moretti et al., 2013). The use of eCG brought estrus manifestation forward in females from the PO1-5 group, from 87.14 hours (control) to 79.08 (eCG800) and 76.73 hours (eCG1000). In contrast, in the PO6+ females the use of eCG had no effect on the WEl, evidencing that the parturition order influenced this variable. Tantasuparuk et al. (2001) reported that the lactation period, nutritional status and exposure to the boar influenced the WEI. Additionally, the order of parturition may also exert an influence, justifying the different results observed in the groups evaluated. In this study, the influence of the parturition order was also evidenced when the effect of the treatments was disregarded. In the PO1-5 group, a higher WEI was observed for sows at their first farrowing, with a gradual reduction of the WEI as the parturition order progressed (Table 2). These data demonstrated the need for special attention to first-farrowing sows. For this class of animals, the use of eCG is especially recommended, which possibly improves the follicular development and thus reduces the WEI.

On the other hand, the WEI of females from the PO6+ group was not influenced by eCG, demonstrating that its use is unnecessary for this class of animals, in this regard. This can be due 
to the fact that these animals present complete uterine development and more homogenous follicular growth in the postpartum period, resulting in smaller variations than those found in younger sows (Knox, 2015). In primiparous or low-birth-order sows, the increase in WEI can be explained by abnormal follicular growth (smaller size follicles) in the immediate postpartum period, resulting in follicles that are not fully responsive to the ovulatory peak of LH (Knox, 2015; Koketsu et al., 2017).

Increased WEI implies a shorter estrus duration and, thus, a smaller ovulation window (Soede et al., 1995ab). An important factor that correlates duration and ovulation period with WEI is the parturition order. Steverink et al. (1999) reported that in primiparous sows the duration of estrus is shorter than in multiparous ones, which was also observed in this study, with a shorter estrus duration in young sows, especially in the primiparous ones, possibly because of the higher WEI.

The number of inseminations had a tendency to increase as the parturition order progressed. This fact is explained by the increased estrus period in these females (Table 2), as well as by the recommendation of inseminations every 12 hours, 24 hours after the start of estrus, adopted on the farm where the experiment was conducted. The duration of estrus may serve as a basis for predicting the time of ovulation. Soede et al. (2011) reported that more than $80 \%$ of the females ovulated in the final third of the estrus, around 30 \pm 3 hours from the beginning of the estrus. Further, the period between the first and the last ovulated follicle varies from 1 to 3 hours in sows with spontaneous ovulation, and up to 6 hours in sows with induced ovulation (Soede et al., 1998). On this basis, there is a possibility to reduce the number of inseminations without reducing the litter size, since the semen maintains its fertilizing capacity for up to 28 hours after insemination (Nissen et al., 1997). However, in many cases there is a large ovulation window, due to the broad variation in the duration of estrus. A sow in heat for 24 hours would be expected to ovulate 16 to 18 hours after estrus onset, while a sow that stands for 72 hours would be expected to ovulate 48 to 54 hours after estrus onset (Safranski and Cox, 2007). Thus, the reduction in the number of inseminations should be evaluated with caution and implemented only with a strict control in estrus detection. In this study, the availability of males for collection and the orientation to perform inseminations every 12 hours, 24 hours after the start of estrus, determined that at least three inseminations were performed for each sow (Table 1).

Regarding gestation and birth rates, the use of gonadotrophins has produced variable results in sows. Studies report that their use does not interfere with gestation and birth rates (Hidalgo et al., 2014), a fact also observed in this study in both younger (PO1-5 group) and older females (group PO6 +). Other studies (Bates et al., 2000; Breen et al., 2006) reported an improvement in the birth rate, although Baroncello et al. (2017) found a decrease in birth rate with the use of eCG or with an association of eCG and $\mathrm{GnRH}$.

The litter size is influenced by the increased WEI period, and the longer the WEl, the fewer piglets are born. Vesseur et al. (1994) observed a litter reduction from 11.7 to 10.6 piglets with the increase of WEI from 4 to 7 days. Similar observations were found in another study (Le Cozler et al., 1997), which also observed litter reduction with the increase of the WEI from 4 to 10 days. In the evaluation of 400 multiparous breeding sows, the ovulation rate decreased from 21.6 to 19.7 oocytes, with the increase of the WEI from 3 to 6 days (Soede et al., $1995 \mathrm{ab}$ ). The decrease in ovulation rate could be a possible cause of reduced litter size with higher WEI (Soede et al., 1995ab; Steverink et al., 1997). In addition, the reduction of the WEI leads to an increase in the estrus period, providing a better maturation of the oocytes, therefore increasing the chances of fertilization and reducing embryo losses (Knox, 2015). In this study, the sows showed a very short WEI (less than 4 days). Nevertheless, the use of eCG determined the reduction of the WEI from 87.1 hours (control) to 79.08 hours with $800 \mathrm{UI}$ of eCG, and 76.7 hours with $1000 \mathrm{UI}$ of eCG. In addition to the reduction of the WEI, the use of $1000 \mathrm{UI}$ of eCG extended the time in estrus from 42.7 to 47.3 hours, favoring the fertilization of oocytes in females from the PO1-5 group. These effects may have been, at least in part, responsible for the increase in the mean number of live piglets 
observed in the PO1-5 group. However, there were no changes in WEI and estrus duration in older females in the PO6+ group, demonstrating the influence of the parturition order on this result.

The parturition order influence was demonstrated in a retrospective study (Tantasuparuk et al., 2000), being observed a smaller number of total and live born piglets in primiparous Landrace and Yorkshire sows. The authors observed an increase in the litter as the parturition order progressed, reaching a peak at the fifth birth. This low number of piglets born in primiparous sows, and extending to their third or fourth farrow is justified by the low rate of ovulation as well as by incomplete uterine development (Gama et al., 1993), and by a not fully active and functional endocrine system (Koketsu et al., 2017). However, in contrast to these data, our study showed no influence of parturition order on the size of the litters of untreated females, with a mean of 12.64 piglets for the PO1-5 group and 12.79 piglets for the $\mathrm{PO} 6+$. Possibly these behavior differences may, at least in part, be attributed to the Naïma sows used in this study, a breed which is highly prolific.

Different studies have revealed differences regarding the effect of gonodatrophins on litter size. Bates et al. (1991), Hazeleger et al. (1999), and Baroncello et al. (2017) reported a reduction in the number of piglets with the use of gonadotrophins, while Kirkwood et al. $(1998,2000)$ reported no effect of gonadotrophins. On the other hand, other studies (Hughes et al., 2000; Vargas et al., 2006) described an increase in litter size with the use of gonadotrophins.

A significant increase in the mean number of piglets obtained in both experimental groups (PO1-5 and PO6+) was observed with the use of eCG. In the OP1-5 group, an increase of 1.5 piglets per litter was observed with the use of $1000 \mathrm{UI}$ of eCG, resulting in an average litter of 14.13 piglets. These results are better than those described by Vargas et al. (2006), who observed an increase of 0.8 live piglets in eCG and hCG treated females.

In this situation, the US\$9.27 paid for $1000 \mathrm{UI}$ of eCG resulted in an increase of US $\$ 30.14$ received by the farmer for the additional 1.5 piglets. In this group, for each dollar invested, there was an increase in revenue of US\$4.0. Extrapolating these values to all sows on the farm, the additional revenue would be very attractive to the farmer. The use of $800 \mathrm{UI}$ of eCG resulted in an intermediate litter, with 13.03 piglets, which was not statistical different from the control group, nor from the eCG1000 group.

Although of smaller magnitude, an increase of one piglet per litter was observed in sows with higher parturition order (group OP6+), by the use of $1000 \mathrm{UI}$ of eCG. The mean litter size of this group was 13.82 piglets, significantly higher than the 12.79 piglets of the control group. In this case, the increase in revenue was of US $\$ 24.85$, which represents an increase of US $\$ 2.68$ for each dollar invested.

Finally, it is important to emphasize that the increased production of live piglets did not interfere in their average weight, nor in the average number of dead and/or mummified piglets. Together, these data demonstrate the feasibility of eCG use to increase the number of live born piglets in sows, regardless of parturition order.

\section{Conclusion}

The administration of eCG does not interfere with the rate estrus induction after weaning; nonetheless, it reduces the WEI and increases the duration of estrus in young sows (parturition order 1 to 5). However, eCG does not interfere with the WEI of sows with a parturition order $\geq$ than 6 . Also, eCG does not interfere in the number of artificial insemination performed, regardless of the sow's parturition order, and provides an increase in the mean number of live piglets. This fact was more significant in sows with a parturition order of 1 to 5. There was no influence in the mean number of dead or mummified piglets, nor the mean weight of piglets at birth.

The increase in the number of live piglets evidences that the investment in eCG results in high rate of return to the farm. The economic analysis revealed a revenue of $400 \%$ of eCG investment in the PO1-5 sows, and $268 \%$ in the PO6+ group. Finally, it was conclude that the dose of $1000 \mathrm{UI}$ eCG after weaning is the most suitable to be used in sows from distinct parturition order. 


\section{Acknowledgments}

The authors are grateful to professor Andre Thaler Neto, for the statistical analysis, and to the Coordination of Improvement of Higher Education Personnel (CAPES) for the scholarship.

\section{References}

Bates RO, Day BN, Britt JH, Clark LK, Brauer MA. Reproductive performance of sows treated with a combination of pregnant mare's serum gonadotropin and human chorionic gonadotropin at weaning in the summer. J Anim Sci. 1991;69(3):894-8.

Bates RO, Kelpinski J, Hines B, Ricker D. Hormonal therapy for sows weaned during fall and winter. J Anim Sci. 2000;78(8):2068-71.

Baroncello E, Bernardi ML, Kummer AD, Wentz I, Bortolozzo FP. Fixed-time post-cervical artificial insemination in weaned sows following buserelin use combined with/without eCG. Reprod Domest Anim. 2017;52(1):76-82.

Breen SM, Rodriguez-Zas SL, Knox RV. Effect of altering dose of PG600 on reproductive performance responses in prepubertal gilts and weaned sows. Anim Reprod Sci. 2006;95(3-4):316-23.

CBRA - Colégio Brasileiro de Reprodução Animal. Manual para exame andrológico e avaliação de sêmen animal. 3 ed. Belo Horizonte: CBRA; 2013. 87 p.

De Rensis F, Hunter MG, Foxcroft GR. Suckling-induced inhibition of luteinizing hormone secretion and follicular development in the early postpartum sow. Biol Reprod. 1993;48(5):964-9.

Gama LL, Johnson RK. Changes in ovulation rate, uterine capacity, uterine dimensions, and parity effects with selection for litter size in swine. J Anim Sci. 1993;71(3):608-17.

Hazeleger W, Bouwman EG, Kemp B. Effect of eCG dose on embryonic survival in the sow after non-surgical embryo transfer. Theriogenology. 1999;51:263.
Hidalgo DM, Friendship RM, Greiner L, Manjarin R, Amezcua MR, Dominguez JC, et al. Influence of lactation length and gonadotrophins administered at weaning on fertility of primiparous sows. Anim Reprod Sci. 2014;149(3-4):245-8.

Hughes AM, Allcock JG, Richardson JS. Strategic use of gonadotropins in first litter sows after weaning. Vet Rec. 2000;146(6):164-5.

Hühn U, Jöchle W, Brüssow KP. Techniques developed for the control of estrus, ovulation and parturition in the east German pig industry: a review. Theriogenology. 1996;46(6):911-24.

Kirkwood RN, Aherne FX, Monaghan PG, Misutka SC. Breeding gilts at natural or a hormone-induced estrus: effects on performance over four parities. J Swine Health Prod. 2000;8(4):177-9.

Kirkwood RN, Ciaran JO, Laksiri AG. Injection of PG600 at weaning of the first litter: Effects on sow lifetime performance. Swine Health Prod. 1998;6(6): 273-4.

Koketsu Y, Tani S, Lida R. Factors for improving reproductive performance of sows and herd productivity in commercial breeding herds. Porcine Health Manag. 2017;3:1.

Knox RV. Recent advancements in the hormonal stimulation of ovulation in swine. Vet Med (Auckl). 2015; 6:309-20.

Le CozlerY, Dagorn J, Dourmad JY, Johansen S, Aumaître A. Effect of weaning to conception interval and lactation length on subsequent litter size in sows. Livest Prod Sci. 1997;51(1-3):1-11.

Moretti AS, Martins SMMK, Andrade AFC, Parazzi LJ, Oliveira ML. Controle farmacológico do ciclo estral. Rev Bras Reprod Anim. 2013;37(2):213-9.

Nissen AK, Soede NM, Hyttel P, Schmidt M, D'Hoore L. The influence of time of insemination relative to time of ovulation on farrowing frequency and litter size in sows as investigated by ultrasonography. Theriogenology. 1997;47(8):1571-82. 
Safranski TJ, Cox NM. Clinical reproductive physiology and endocrinology on sows: Mating management. In: Youngquist RR, Threlfall WR (Eds.). Current Theraphy in Large Animal Theriogenology. 2th ed. St. Louis: Saunders; 2007. p. 738-49.

Soede NM, Hazeleger W, Kemp B. Follicle size and the process of ovulation in sows as studied with ultrasound. Reprod Dom Anim. 1998;33(3-4):239-44.

Soede NM, Langendijk P, Kemp B. Reproductive cycles in pigs. Anim Reprod Sci. 2011;124(3-4):251-8.

Soede NM, Wetzels CC, Zondag W, Hazeleger W, Kemp B. Effects of second insemination after ovulation on fertilization rate and accessory sperm count in sows. J Reprod Fertil. 1995b;105(1):135-40.

Soede NM, Wetzels CC, Zondag W, Koning MA, Kemp $B$. Effects of time of insemination relative to ovulation, as determined by ultrasonography, on fertilization rate and accessory sperm count in sows. J Reprod Fertil. 1995a;104(1):99-106.

SAS Institute Inc. SAS/STAT ${ }^{\circledR} 9.2$ User's Guide. Cary, NC: SAS Institute Inc.; 2008.

Steverink DW, Soede NM, Bouwman EG, Kemp B. Influence of insemination-ovulation interval and sperm cell dose on fertilization in sows. J Reprod Fertil. 1997;111(2):165-71.

Steverink DW, Soed NM, Groenland GJ, van Schie FW, Noordhuizen JP, Kemp B. Duration of estrus in relation to reproduction results in pigs on commercial farms. J Anim Sci. 1999;77(4):801-9.
Tantasuparuk W, Lundeheim N, Dalin AM, Kunavongkrit A, Einarsson S. Reproductive performance of purebred landrace and Yorkshire sows in Thailand with special reference to seasonal influence and parity number. Theriogenology. 2000;54(3):481-96.

Tantasuparuk W, Lundeheim N, Dalin AM, Kunavongkrit A, Einarsson S. Weaning-to-service interval in primiparous sows and its relationship with longevity and piglet production. Livest Prod Sci. 2001;69(2):155-62.

Vargas AJ, Bernardi ML, Wentz I, Borchardt Neto G, Bortolozzo FP. Time of ovulation and reproductive performance over three parities after treatment of primiparous sows with PG600. Theriogenology. 2006;66(8):2017-23.

Varley MA, Foxcroft GR. Endocrinology of the lactating and weaned sow. J Reprod Fertil Suppl. 1990;40:47-61.

Vesseur PC, Kemp B, den Hartog LA. The effect of the weaning to oestrus interval on litter size, live born piglets and farrowing rate in sows. J Anim Physiol Anim Nutr. 1994; 71(1-5):30-8.

Ziecik A, Krzymowska H, Tilton JE. Porcine LH levels during the estrous cycle, gestation, parturition and early lactation. J Anim Sci. 1982;54(6):1221-6. 